\title{
The evolution of sexually transmitted infections in Romania
}

\author{
Vasile Benea ${ }^{1 *}$, Simona Roxana Georgescu', Viorica Gheorghiu², Mircea Tampa', Mihaela-Anca Benea-Mălin² \\ From The 9th Edition of the Scientific Days of the National Institute for Infectious Diseases Prof Dr Matei Bals \\ Bucharest, Romania. 23-25 October 2013
}

\section{Background}

The objective of the present study was to analyze the evolution of incidence of some sexually transmitted infections (STI) in Romania in the transition period.

\section{Methods}

We had in view to evaluate the evolution of incidence of syphilis, gonorrhea, $C$ trachomatis genitally infections and HIV infection/AIDS and to identify the main factors implicated in this evolution.

\section{Results}

In 2012 were recorded 1,702 new cases of syphilis. The incidence of syphilis has risen steadily from 7.1 per ten thousand in 1986 to 19.8 in 1989 and to 58.5 in 2002 and decreased to 7.93 per ten thousand in 2012 . The incidence of congenital syphilis was also increasing, from no cases in 1986 to 423 cases in 2001 and (after introduction of new criteria in 2004) decreased to 10 cases in 2011. Paradoxically, the incidence of gonorrhea is decreasing, from 57.4 per ten thousand in 1986 to 35.7 in 1989 and to 1.49 per ten thousand in 2012 (314 cases). In 201257 new cases of $C$ trachomatis genitally infections were reported ( 0.62 per ten thousand). The prevalence of HIV infection in patients with STI tested at Dermato-venerology Centre Bucharest is around $0.51 \%$ (3.22\% in 2012).

Those at greatest risk for STD are the young, economically deprived, residents of the inner city.

\section{Conclusion}

STI are a public health problem of major significance in Romania. Between mains factors that promote the increasing of STI (the incidence of gonorrhea and $C$ trachomatis

\footnotetext{
* Correspondence: beneav@yahoo.com

'Department of Dermatology, Clinical Hospital of Infectious and Tropical

Diseases "Dr. Victor Babeş", Bucharest, Romania

Full list of author information is available at the end of the article
}

genitally infections is underestimated due to the unreference of all cases) are the modification of sexual behavior, prostitution, degradation of socioeconomic condition, and deficiencies in health behavior.

\section{Authors' details}

'Department of Dermatology, Clinical Hospital of Infectious and Tropical Diseases "Dr. Victor Babeş", Bucharest, Romania. 2Public Health Institute Bucharest, Romania.

Published: 16 December 2013

doi:10.1186/1471-2334-13-S1-O36

Cite this article as: Benea et al:: The evolution of sexually transmitted infections in Romania. BMC Infectious Diseases 2013 13(Suppl 1):O36.

Submit your next manuscript to BioMed Central and take full advantage of:

- Convenient online submission

- Thorough peer review

- No space constraints or color figure charges

- Immediate publication on acceptance

- Inclusion in PubMed, CAS, Scopus and Google Scholar

- Research which is freely available for redistribution

Submit your manuscript at www.biomedcentral.com/submit
() Biomed Central
C Biomed Central

○ 2013 Benea et al; licensee BioMed Central

Atributionea et al; licensee BioMed Central Ltd. This is an Open Access article distributed under the terms of the Creative Commons any medium, provided the original work is properly cited. 